\title{
Environmental Psychology Approaches Within the Relationship of Nature and Health in terms of Landscape Architecture
}

DOI: $10.26466 /$ opus.910271

\author{
Elif Karaca * - Mehmet Karaca ** \\ * Asst. Prof. Dr., Çankırı Karatekin University, Kızılırmak Vocational School, , Çankırı/Turkey \\ E-Mail: elifboyaci82@gmail.com \\ ORCID: $0000-0002-3041-9318$ \\ ** Dr., Metroplan Consulting and Engineering, Ankara/Turkey \\ E-Mail: mehmetkaraca.info@gmail.com \\ ORCID: $\underline{0000-0002-8826-243 X}$
}

\begin{abstract}
For a while, today's modern people have been struggling with various problems which threaten their health including climate change, water and food scarcities, depression etc. Also, most recently, they have been faced with a more complicated- unfamiliar problem, pandemic. And in the future, what kind of different problems to be faced to threaten their health cannot be predicted. This situation underlines boldly the obligation to support people health before then it has been lost. And, at the point of supporting health, the phenomenon of nature emerges. Nature offers low-cost, non-intrusive solutions for human health and well-being, and the landscape architecture profession also plays an important role in enhancing the relationship with nature. Today, many studies are emphasizing the positive effects of exposure to nature on health and the relationship between nature and health is generally explained within the scope of various theories put forward by environmental psychology. Within the scope of this study, initially, the relationship between nature and health is reviewed in the context of theories put forward by environmental psychology. Subsequently, suggestions are offered regarding the design processes, assessing design approaches supporting health in the aspect of landscape architecture which has an important role to increase the interaction with nature.
\end{abstract}

Key Words: $\quad$ Health, Nature, Landscape Architecture, Environmental Psychology. 


\section{Doğa ve Sağlık İlişkisini Ele Alan Çevre Psikolojisi Yaklaşımlarının Peyzaj Mimarlığı Açısından Değerlendirilmesi}

Öz

Günümüz insanı bir süredir iklim değişikliği, su ve yiyecek kıtll̆ğl, depresyon gibi sağlığını tehdit eden pek çok problemle başa çımmaya çalışmaktadır. Yakın bir zamanda ise ona hiç tanıdık olmayan çok daha karmaşık bir problem olan "pandemi" ile karşı karşıya kalmıştır ve ileride de să̆lığın tehdit edebilecek ne tür farklı bir problemle karşılaşacağını tahmin edememektedir. Bu durum insanların sağlı̆̆ın bozulmadan önce desteklenmesi gerektiğinin farkına çok daha fazla varmasına neden olmuştur. Sağlı̆̆ın desteklenmesi noktasında ise karşımıza "doğa" kavramı çıkmaktadır. Doğa, insan sağlı̆̆ı ve refahı için dü̧̧ük maliyetli, müdahaleci olmayan çözümler sunmakta ve peyzaj mimarlığı mesleği de doğa ile ilişkiyi artırmada önemli bir rol oynamaktadır. Günümüzde doğaya maruz kalmanın să̆lık üzerindeki olumlu etkilerini gösteren çok sayıda çalışma bulunmakta ve doğa ile sağlık arasındaki ilişki genellikle çevre psikolojisinin ortaya koyduğu çeşitli teoriler kapsamında açıklanmaktadır. Bu çalışma kapsamında da öncelikle doğa ve sağlık arasındaki ilişki çevre psikolojisinin ortaya koyduğu teoriler çerçevesinde ele alınmıştır. Daha sonra sağhl̆̆ı destekleyen tasarım yaklaşımları doğayla etkileşimin artırılmasında anahtar rolü olan peyzaj mimarlı̆̆ı açısından değerlendirilerek tasarım süreçlerine yönelik önerilerde bulunulmuştur.

Anahtar Kelimeler: Sağlık, Doğa, Peyzaj Mimarlı̆̆̆, Çevre Psikolojisi. 


\section{Introduction}

Today's new concept of health is moving towards a different point from the common approach based on pathogenic health, which sees diseases just as a biological process occurring as a result of exposure to a particular pathogen.

This new concept defines health using the term salutogenesis (Antonovsky, 1993), which has been developed as a response to the pathogenic approach and sees health as a multi-dimensional concept including not only biological but also psychological and social effects. The expression of WHO (2017), "not only the absence of illness and disability in the body of the individual but a complete physical, mental and social well-being of the person", is also parallel with that new concept.

Shortly, this concept focuses on promoting health and well-being.

At that point, nature arises as an important phenomenon. The effect of engagement with nature and the natural environment on human health and well-being has widely discussed and the accumulated evidence indicates that being exposed to natural areas has several health benefits (Bratman et al., 2019; MacIntyre et al., 2020; Steg et al., 2012).

Our belief in the healing power of nature has dated thousands of years ago. The idea of being in contact with nature being healthy is, intuitively, valid. Therefore, for a long time, people did not feel the need to show or measure the contribution of nature to health.

However, with the increasing importance of the relationship between the built environment and health, different theories have been put forward, specifically in the field of environmental psychology which tries to explain the relationship between nature and health. In this context, lots of research has been realised. Some research evaluates those viewing nature through a window (Honold et al., 2016; Ulrich, 1984) or living in green environments with nature high amount of (Cohen-Cline et al., 2015) or accessing parks and green places. And points out that all of those promote the positive relationship between health and nature.

Considering nature offers a low-cost, non-invasive solution for human health and well-being (MacIntyre et al., 2020), the profession of landscape architecture has a key role to increase the relationship and contact with nature 
and human being (Jackson, 2003). In terms of landscape architecture, in addition to revealing the connections between nature and health, the question of "how the designs to support this relationship should be" also arises.

In this research, initially, the mechanisms of the relationship between nature and health are mentioned. Subsequently, four approaches biophilic design, social/participant design, evidence-based design and salutogenic design are evaluated with the aspect of landscape architecture, three of which are within the scope of environmental psychology and the fourth is the salutogenic approach based on Antonovsky (1993).

\section{Mechanisms Explaining the Relationship Between Nature and Health}

One of the central aspects of health research is to identify the mechanisms that explain the observed health effects (Frumkin et al., 2017). In this direction, various theoretical studies which discuss the mechanisms explaining nature's effects on human health and well-being take place in the literature (BedimoRung et al., 2005; Calogiuri and Chroni, 2014; Hartig et al., 2014; Kuo, 2015; Lachowycz and Jones, 2011; Shanahan et al., 2015; van den Bosch and Ode Sang, 2017).

These mechanisms most generally get associated with the topics of regulation of ecosystem services, physical activity, social cohesion and stress reduction.

\section{Regulation of Ecosystem Services}

Ecosystem services are defined as the benefits that people obtain directly or indirectly from functioning ecosystems (Aerts et al., 2018) and it is one of the theories used to explain the effects of nature on health.

This theory states that nature can contribute to health and well-being by increasing positive effects as well as reducing negative effects.

For example, antimicrobial volatile organic compounds, so-called phytoncides, are released by plants and have reduction effects on blood pressure and increase immune function (Kuo, 2015; Li et al., 2009) or the air in forested and mountainous areas and near the flowing water contains a high concentration of negative air ions that reduce depression (Kuo, 2015; Li et al., 2010). Trees 
reduce the levels of air pollution and also heal the air quality by cooling urban areas and reduce the buildings energy demands (Hartig et al., 2014).

However, on the contrary to these positive effects, some tree species (Salix nigra, Picea engelmannii, Eucalyptus gunnii, Populus tremuloides, Pinus clausa, Salix babylonica etc.) contribute negatively to air pollution by releasing hydrocarbons (Benjamin and Winer, 1998). Also, some plants (Quercus stellata., Juglans nigra, Salix nigra, Ulmus alata etc.) produce pollens that can make allergies or asthma in sensitive people (DellaValle et al., 2012).

Therefore, all those examples given above show that the impacts of ecosystem services on health can be variable.

\section{Physical Activity}

Physical activities support our physical and mental health throughout a lifetime. It provides a wide range of health benefits to the prevention and/or amelioration of diseases such as obesity, cardiovascular diseases, some cancers, diabetes, some mental disorders or osteoporosis (Bauman et al., 2016; Frumkin et al., 2017; Lee et al., 2012).

Green areas affect a person's activeness by providing suitable areas for several activities. So, nature can be said an important promoter of physical activity. For example, places where people can contact nature such as parks, school gardens or university campuses can increase the period of physical activity of both children and adults (Bancroft et al., 2015; Hunter et al., 2015; Shanahan et al., 2016).

Some of the evidence props that the physical activities performed outdoor provide more benefits than indoor with the same effort (Barton et al., 2016). Therefore, physical activity is acknowledged as a convenient mechanism for the health benefits obtained from nature.

But it is worth noting that, just being within a green area is not always mean being active. Because green areas may not only be used for physical activity but also be attractive to people by offering different experiences such as entertainment or relaxation.

Physical activity is more related to self-motivation and therefore, merely increasing the amount of green area may not provide more physical activity 
to be done there. Hence, in parallel with these evaluations, the positive relationship between nature and physical activity can be said so complex (Maas et al., 2008; Steg et al., 2012).

\section{Social Cohesion}

Same as the physical activity aforesaid, the positive association between social relationships and health and well-being have also been supported by numerous studies (Hartig et al., 2014; Holt-Lunstad et al., 2010; Nieminen et al., 2010).

Some of the studies indicate that the green areas can promote social cohesion and the sense of community among the people living within the same environments, specifically neighbourhood level (Dadvand et al., 2016; Home et al., 2012; Maas et al., 2009; Steg et al., 2012; Sullivan et al., 2004).

Sugiyama et al. (2008) found that the social cohesion and interaction locally are related to the perceived greenery of the neighbourhood. Also, de Vries et al. (2013) indicate a relation between streetscape greenness and perceived social cohesion at the neighbourhood scale, both on the quantity and, more strongly, the quality of green areas.

However, it should not be omitted that the social cohesion within a neighbourhood is not amenable to empirical research and this makes it difficult to determine whether relationships with environmental characteristics are causal or not. (Hartig et al., 2014).

\section{Stress Reduction}

This mechanism is often associated with the restorative or stress-relieving effects of nature and explained with two main theories: the stress recovery theory and the attention restoration theory.

Both of these theories posit that natural environments have restorative potential due to moderating physiological arousal or mental fatigue (Berto, 2014; Reeves et al., 2019) and this reduction in psychological and physiological stress is thought to increase the health and well-being benefits.

With reference to stress recovery theory, people have a psych-evolutionary preference for natural elements (Ulrich et al., 1991). Positive physiological 
and psychological processes occur automatically during exposure to natural elements and help people quick relief from stress (Yang et al., 2021).

On the other hand, attention restoration theory (Kaplan et al., 1998) which is proposed to restore attention capacity and relieve mental fatigue asserts the importance of the relationship with nature for mental functionality. According to this theory; after a short exposure to nature, the cognitive capacity to focus attention is restored because contact with nature enhances the inhibitory mechanism on which directed attention depends (Li and Sullivan, 2016).

Attention restoration theory suggests that it must have four properties (being away, fascination, coherence, compatibility) or the level of these properties must be relatively higher, for an environment to be healing and to regenerate the capacity of attention (Franěk et al., 2018; Herzog et al., 2003; Kaplan, 1995; Moran, 2019).

Both of the theories are based on the biophilia hypothesis. According to this hypothesis, the positive effects of exposure to natural factors arise from a biological link between humans and the natural world (Gillis and Gatersleben, 2015). This situation drives people to contact with nature and other life forms.

\section{Design Approaches Supporting Health and Well-Being, Context of Land- scape Architecture}

,For many years, efforts have been made to design environments that support human health and healthy behaviour, and different design approaches have emerged in this direction.

Some of these approaches are those biophilic design, social/participant design, evidence-based design and salutogenic design, three of which are within the scope of environmental psychology and the fourth is the salutogenic approach based on Antonovsky.

\section{Biophilic Design}

Biophilia can be defined as an inherent human tendency to natural systems and processes (Kellert et al., 2011) and it urges us to affiliate with other forms of life (Xue et al., 2019). 
Biophilia is also defined as the tendency to depend on nature, which remains critical for people's physical and mental health and well-being in the modern world (Kellert et al., 2011; R. Kellert and Wilson, 1993; Wilson, 1994).

Today, a growing number of scientific studies on this subject show that the tendency to depend on nature has significant effects on people's physical and mental health and well-being. In this scope, contact with nature has a profound effect on the quality of life.

Although the need for beneficial contact with nature remains critical for people's health and well-being, today's dominant approach of modern architecture and landscape design largely treats nature as an obstacle to overcome or an unrelated issue (Kellert and Calabrese, 2015). At this point, the biophilic design aims to create quality living environments for people in the modern world, that enhance their health and well-being.

The most important aspect of biophilic design is to benefit from the inherent link between the human and natural environment and to provide people with to feel of it within them (Gillis and Gatersleben, 2015).

The biophilic design tries to overcome the shortcomings of modern architectural and landscape applications by creating a new framework for a satisfying nature experience in the built environment (Browning et al., 2014) (Figure 1,2$)$.

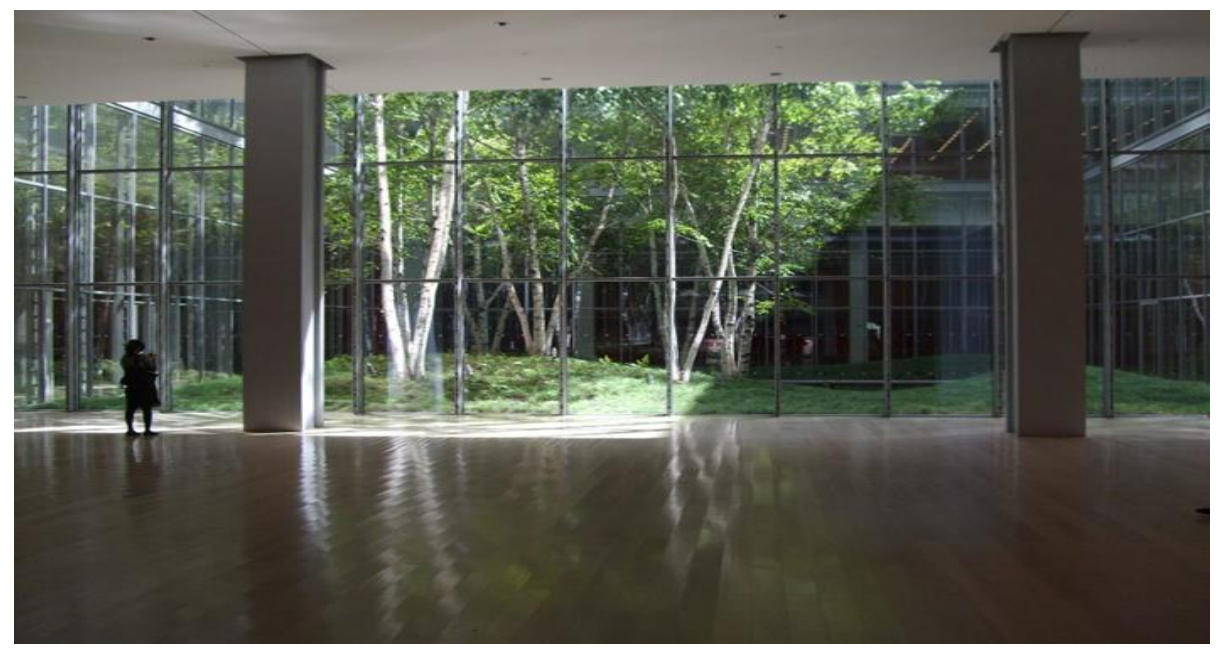

Figure 1. The NY Times Building Moss and Birch Garden (White, 2013) 


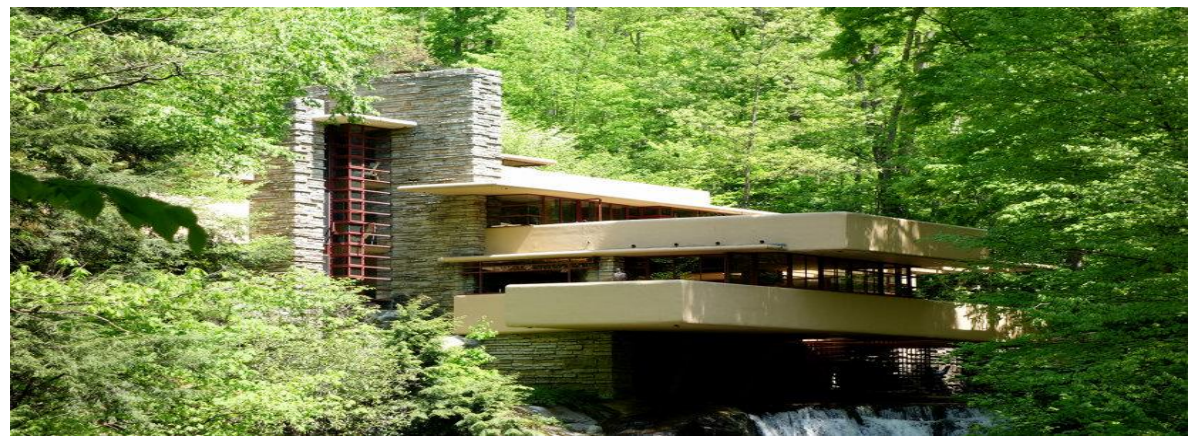

Figure 2. Fallingwater (the Kaufmann residence) by Frank Lloyd Wright (Hunt, 2020)

Therefore, as Kellert (2016) stated, landscape designs that reconnect people with nature, reduce people's stress and create healthier living and working spaces are very important (Figure 3,4).

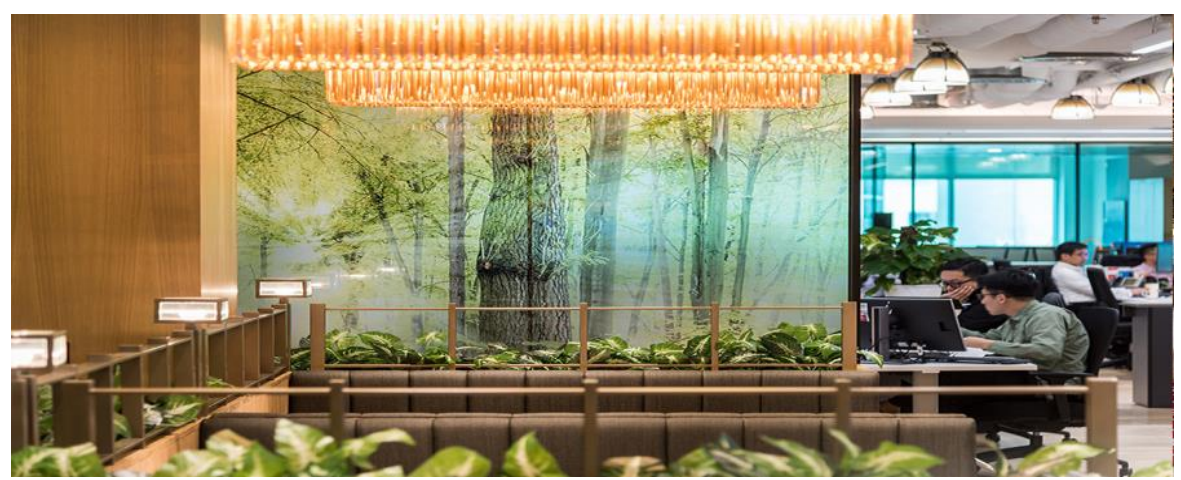

Figure 2. Li and Fung, Hong Kong (Biophilicworkplace, 2020)

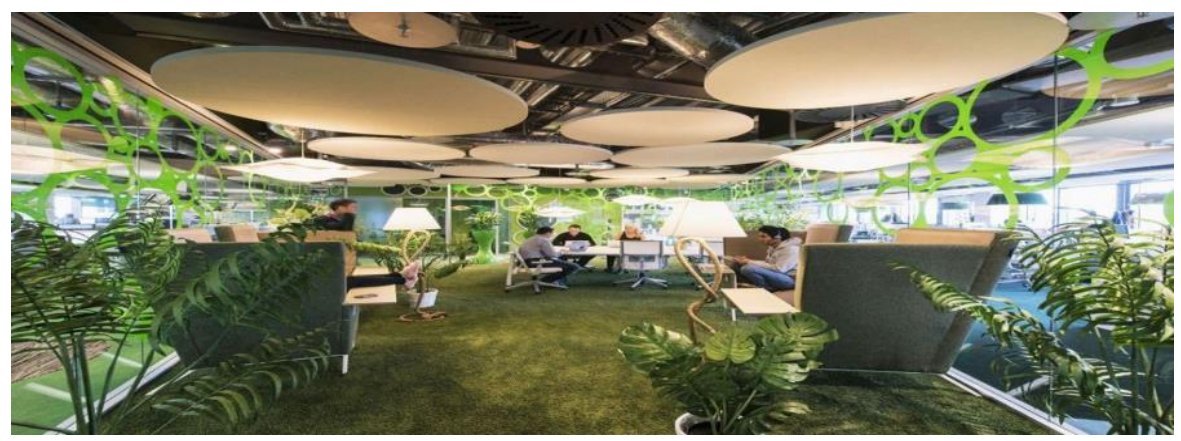

Figure 4. Google's Office in Dublin (Biophilicdesign, 2020) 
Kellert and Calabrese (2015) define three types of nature experiences that constitute the basic categories of the biophilic design framework. These are respectively;

- Direct experience of nature: It expresses real contact with the environmental features such as plants, water, air, natural light, animals etc. in the built environment.

- Indirect experience of nature: It expresses contact with the imitation or image of nature or exposure to processes and patterns characteristic of the natural world. These include naturalistic shapes and forms, natural colours, simulation of natural light and air, biomimicry etc.

- Experience of space and place: It refers to the characteristic spatial features of the natural environment that improve human health and wellbeing. For example, enhancing the sense of place, organizing mobility etc.

If we evaluate the above-mentioned components, it is easily realised that most of them are essentially the basic elements of landscape design. Despite this, due to the wrong usage or using never of these elements, biophilic landscape design can not be created as required.

Naturally, depending on the project, which elements to be used is changeable. However, the important point is that the biophilic design elements should never be used piecemeal and disconnected from each other to create just a decorative design but should be considered in a way that creates ecological integrity.

\section{Salutogenic Design}

With the aim of creating "Psychosocially Supportive Design", which is a theory and framework that promote health through the design of the physical environment, in the 1990s architect Alan Dilani suggested the use of Antonovsky's salutogenic theory (Ziegler, 2014). According to Dilani (2015) "Implementation of psychosocially supportive design supports the sense of coherence that stimulates and engages people, both mentally and socially".

Salutogenic design is about providing active health rather than just focusing on treating illness (Mazuch, 2017). It highlights the design factors that inspire both the designers and planners to create a healthy society (Dilani, 2015) 
for urban designs that stimulate healthy behaviour and thereby supporting the prevention of diseases and promotion of health.

From the perspective of landscape architecture, landscape architects can enhance salutogenic environments by protecting nature and increasing interaction with green spaces, such as (Karaca, 2018);

- designing green spaces supporting physical activity

- creating spaces supporting urban agriculture, such as edible gardens, community gardens etc. (Figure 5).

- creating places encouraging connection with nature specifically for patients, staff and visitors (Figure 6).

- creating places providing nature and children relationship

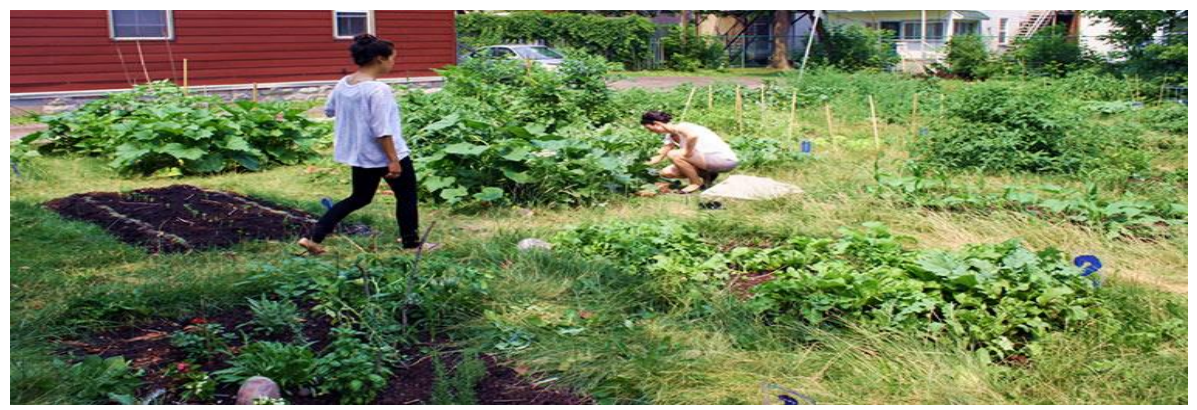

Figure 5. University of Ottawa- Green Campus Community Garden (OttawaUniversity, 2020)

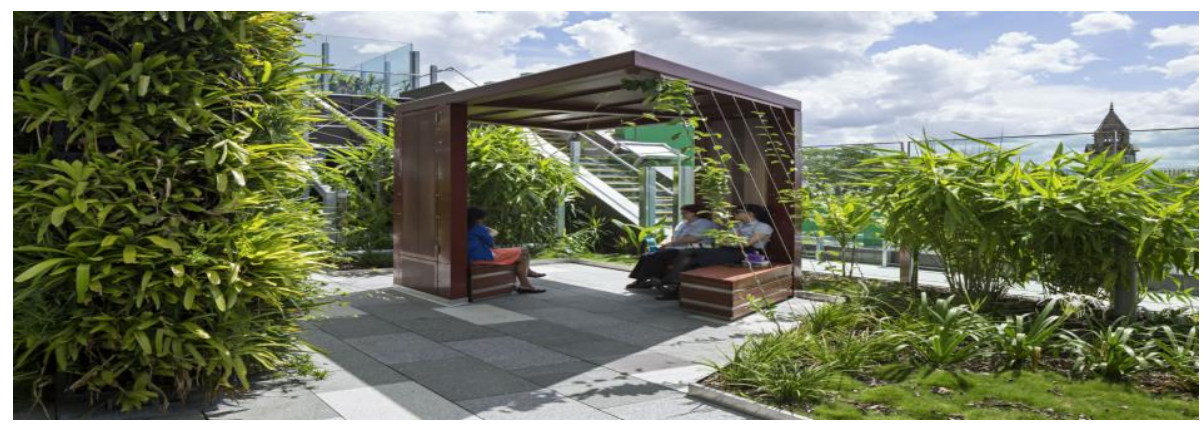

Figure 6. Lady Cilento Children's Hospital (Buildingbetterhealthcare, 2017) 
Also, the salutogenic design refers to encourage social and physical opportunities by using nature for promoting health and wellbeing and landscape architects can also enhance salutogenic environments by strengthening social cohesion, by those (Karaca, 2018);

- creating attractive places and meeting points

- designing safety and quality parks and recreation areas

- enhancing cultural activities where people socialized

- creating public places for different groups

\section{Social/ Participant Design}

Built environments are the places getting different by culture or region and becoming meaningful with whom live in there. To be livable and quality, these places should give a sense of tranquillity, happiness and confidence as well as should be suitable for users' lifestyle and also meaningful for them. Thus, people can feel they belong to these places.

In the definition for the concept of quality, Türkoğlu (1993) emphasises that the most critical indicator of quality is the response of the environment to the lifestyles, social and psychological expectations and needs of users.

Landscape design is a complex process that is related to people's multiple needs and this process should be shaped within the framework of the basic values of the users' expectations and needs to be pleased and satisfied. Hence, the primary objective of the design should be focused on creating an environment that supports human behaviour rather than creating just a physical product.

The relationship between designers and users is characterized as a gap (Göregenli, 2010). The failure to fill that gap, that is, to get a one-to-one due relationship between the designers and the users causes that design for the users whose structure, characteristics and expectations are unknown. This often causes conflict between the users' needs and expectations and the designers' estimations. And at the end of the day, emerges a poor relationship between the users and the designed environment.

Today, the interrelation between the human's general well-being and the physical world where living is accepted undisputedly. Therefore, one of the 
most important focus in the design process can be mentioned as the relationship between human satisfaction and happiness and environmental design (Göregenli, 2010).

It is a necessity to determine the subjective expectations of the users, besides determining the objective properties constituting a quality environment. For this reason, today, carrying out the landscape design process in line with user expectations has been become an important issue.

Being user-oriented, that is, placing the user's perspective at the centre of the design process has become an important requirement of any design (Mura, 2014). Within the emerging direction, the social/participatory design approach describes a perspective that brings users' needs and expectations forefront and gives priority to methods that realize them.

Participatory landscape design can be defined as the design process that engages stakeholders and designers in the creative process and improves the results for end-users (Bartlett, 2014). It engages participants in a collaborative process for environmental change. Particularly in large-scale landscape projects, participatory landscape design arouses a sense of ownership that supports the sustainability of the space (Bartlett, 2014; Crewe and Forsyth, 2003).

User-oriented landscape design makes the cities and green areas more livable with an environmentally friendly approach. And so, the landscape designs created in this way constitute a sense of unity and pride among people (Othman et al., 2015).

The social design also provides opportunities for people to actively participate in designing green spaces and improve their social interactions with society (Middle et al., 2014; Othman et al., 2015; Rasidi et al., 2012). The places build in this way give people the right to responsibility and control over their own lives, as well (Mahdavinejad and Abedi, 2011).

Depending on all these, landscape spaces designed with a user-oriented approach become places where users interact and are meaningful for them.

\section{Evidence-Based Design}

The evidence-based approach, as an important part of decision making, is a process that consists of the evaluation of academic evidence and thus integrates this knowledge obtained into professional practices. 
Originated in the field of medical practices, this approach has become widespread after seen be able to use also as a practical model to design health facilities; and in time named as "evidence-based design " (Fagan, 2017).

The evidence-based design is a process whereby the best available evidence obtained from research and implementation is used carefully, logically and clearly to make critical decisions for the design of a project (Hamilton and Watkins, 2008).

Over the past decade the evidence-based design has expanded into the fields of architecture and landscape architecture, and today, it has evolved into health design, which is a branch of both architecture and landscape architecture (Sidenius et al., 2017).

Evidence-based landscape architecture is defined by Brown and Corry (2011) as "the deliberate and explicit use of scientific evidence in making decisions about the use and forming of the land" (Jansson et al., 2019).

Brown and Corry (2011) suggested a process for evidence-based landscape architecture with four stages:

- Formulating a clear goal or question based on the problem or the user's expectation

- Researching the relevant scientific literature

- Evaluating the evidence critically with regards to both validity and usefulness

- Synthesizing the findings and applying them to the problem

Today, society is faced with serious and complex problems such as global climate change, obesity, and water scarcity that landscape architects can solve or at least produce adaptive solutions. Therefore, landscape architecture has the potential to be as important as medicine for the future of nature and human health (Brown and Corry, 2011; Fagan, 2017).

Evidence-based landscape design aims to maximize positive outcomes for the health and well-being of users. Therefore, for landscape designs to perform the desired functions, evidence-based design should be incorporated into the conventional design approaches which are just based on observation, experience or personal opinion.

When landscape architects design sustainable and livable environments, they will positively support the health and well-being of the community. 


\section{Conclusion}

While today's people are being faced with many problems such as climate change, water and food scarcity, decreased natural environments and pandemic which is a new much more complex problem simultaneously, in the third era of health, new ways to improve our personal and public health are being tried to find out.

Therefore, figuring out new ways to protect our personal and public health and to increase awareness of existing solutions have become much more important. In this regard, the necessity of interdisciplinary studies among each professional discipline (architecture, landscape architecture, environmental psychology, public health and medicine etc.), which has different responsibilities, has emerged.

In this study, four main design approaches suggested by environmental psychology to create healthy environments are introduced and additionally, through the point of landscape architecture, these approaches are evaluated, giving some suggestions.

Nature offers a low-cost, non-invasive solution for human health and well-being (MacIntyre et al., 2020). In this context, the landscape architecture profession has a key role to increase relation and contact with nature.

Therefore, these health-supporting design approaches to be used in landscape architecture should be thought that can be used as an opportunity to improve health by ensuring the continuity of nature experience

\section{References}

Aerts, R., Honnay, O. and Van Nieuwenhuyse, A. (2018). Biodiversity and human health: Mechanisms and evidence of the positive health effects of diversity in nature and green spaces. $\mathrm{Br}$ Med Bull, 127(1), 5-22. https://doi.org/10.1093/bmb/ldy021

Antonovsky, A. (1993). The structure and properties of the sense of coherence scale. Social Science and Medicine, 36(6), 725-733. httpsf//doi.org/https://doi.org/10.1016/0277-9536(93)90033-Z

Bancroft, C., Joshi, S., Rundle, A., Hutson, M., Chong, C., Weiss, C. C., Genkinger, J., Neckerman, K. and Lovasi, G. (2015). Association of proximity and density of parks and objectively measured physical activity in the United States: A 
systematic review. Social science andamp; medicine (1982), 138, 22-30. https://doi.org/10.1016/j.socscimed.2015.05.034

Bartlett, M. L. (2014). Participatory landscape design detroit: A tool for environmental education and action. Michigan Journal of Sustainability, 2, 12-21. https://doi.org/10.3998/mjs.12333712.0002.008

Barton, J., et al. (2016). Green exercise, health and a dose of nature green exercise: Linking nature, health and well-being. J. Barton, R. Bragg, C. Wood and J. Pretty. London, Routledge, Taylor \& Francis Group: 26-36.

Bauman, A., Merom, D., Bull, F. C., Buchner, D. M. and Fiatarone Singh, M. A. (2016). Updating the evidence for physical activity: Summative reviews of the epidemiological evidence, prevalence, and interventions to promote "Active Aging". Gerontologist, 56(2), 268-280. https://doi.org/10.1093/geront/gnw031

Bedimo-Rung, A. L., Mowen, A. J. and Cohen, D. A. (2005). The significance of parks to physical activity and public health: a conceptual model. Am J Prev Med, 28(2 Suppl 2), 159-168. https://doi.org/10.1016/j.amepre.2004.10.024

Benjamin, M. T. and Winer, A. M. (1998). Estimating the ozone-forming potential of urban trees and shrubs. Atmospheric Environment, 32, 53. https://doi.org/10.1016/s1352-2310(97)00176-3

Berto, R. (2014). The role of nature in coping with psycho-physiological stress: A literature review on restorativeness. Behav Sci (Basel), 4(4), 394-409. https://doi.org/10.3390/bs4040394

Biophilicdesign. (2020). Biophilic design - what is it? Retrieved 12 May 2021 from https://floresy.online/trends/biophilic-design/

Biophilicworkplace. (2020). Biophilic office design in the post COVID-19 workplace. Space Matrix. Retrieved 15 May 2021 from https://www.spacematrix.com/content/love-nature-biophilic-office-design-trend-modern-workplaces

Bratman, G. N., Anderson, C. B., Berman, M. G., Cochran, B., de holt, S., Flanders, J., Folke, C., Frumkin, H., Gross, J. J., Hartig, T., Kahn, P. H., Kuo, M., Lawler, J. J., Levin, P. S., Lindahl, T., Meyer-Lindenberg, A., Mitchell, R., Ouyang, Z., Roe, J., Scarlett, L., Smith, J. R., van den Bosch, M., Wheeler, B. W., White, M. P., Zheng, H. and Daily, G. C. (2019). Nature and mental health: An ecosystem service perspective. Science Advances, 5(7), 1-14. https://doi.org/10.1126/sciadv.aax0903

Brown, R. D. and Corry, R. C. (2011). Evidence-based landscape architecture: The maturing of a profession. Landscape and Urban Planning, 100(4), 327-329. https://doi.org/10.1016/j.landurbplan.2011.01.017 
Browning, W. D., Ryan, C. O., and Clancy, J. O. (2014). 14 Patterns of Biophilic Design https:/www.terrapinbrightgreen.com/reports/14-patterns/

Buildingbetterhealthcare. (2017). Designing gardens for healing and health. Building better healthcare. Retrieved 15 May 2021 from https://www.buildingbetterhealthcare.com/news/article page/Designing gardens for healing and health/130540

Calogiuri, G. and Chroni, S. (2014). The impact of the natural environment on the promotion of active living: an integrative systematic review. BMC Public Health, 14, 873. https://doi.org/10.1186/1471-2458-14-873

Cohen-Cline, H., Turkheimer, E. and Duncan, G. E. (2015). Access to green space, physical activity and mental health: A twin study. Journal of Epidemiology and Community Health, 69(6), 523-529. https://doi.org/10.1136/jech-2014-204667

Crewe, K. and Forsyth, A. (2003). LandSCAPES: A typology of approaches to landscape architecture. Landscape Journal, 22(1), 37-53. http://www.jstor.org/stable/43324465

Dadvand, P., Bartoll, X., Basagaña, X., Dalmau-Bueno, A., Martinez, D., Ambros, A., Cirach, M., Triguero-Mas, M., Gascon, M., Borrell, C. and Nieuwenhuijsen, M. J. (2016). Green spaces and General Health: Roles of mental health status, social support, and physical activity. Environ Int, 91, 161-167. https://doi.org/10.1016/j.envint.2016.02.029

de Vries, S., van Dillen, S. M. E., Groenewegen, P. P. and Spreeuwenberg, P. (2013). Streetscape greenery and health: Stress, social cohesion and physical activity as mediators. Social Science and Medicine, 94, 26-33. https://doi.org/https://doi.org/10.1016/j.socscimed.2013.06.030

DellaValle, C. T., Triche, E. W., Leaderer, B. P. and Bell, M. L. (2012). Effects of ambient pollen concentrations on frequency and severity of asthma symptoms among asthmatic children. Epidemiology (Cambridge, Mass.), 23(1), 55-63. https://doi.org/10.1097/EDE.0b013e31823b66b8

Dilani, A. (2015). The beneficial health outcomes of salutogenic design https://www.designandhealth.org/ 14.02.2021

Fagan, E. (2017). Evidence-based design: Structured approaches in leading landscape architecture practice. Master, Kansas State University, Landscape and Regional \&Community Planning. Manhattan.

Franěk, M., Šefara, D., Petružálek, J., Cabal, J. and Myška, K. (2018). Differences in eye movements while viewing images with various levels of restorativeness. Journal of Environmental Psychology, 57, 10-16. https://doi.org/https://doi.org/10.1016/j.jenvp.2018.05.001 
Frumkin, H., Bratman, G. N., Breslow, S. J., Cochran, B., Kahn, P. H., Jr., Lawler, J. J., Levin, P. S., Tandon, P. S., Varanasi, U., Wolf, K. L. and Wood, S. A. (2017). Nature contact and human health: A research agenda. Environ Health Perspect, 125(7), 1-18. https://doi.org/10.1289/EHP1663

Gillis, K. and Gatersleben, B. (2015). A review of psychological literature on the health and wellbeing benefits of biophilic design. Buildings, 5(3), 948-963. https://doi.org/10.3390/buildings5030948

Göregenli, M. (2010). Çevre psikolojisi-İnsan mekan ilişkileri. İstanbul: İstanbul Bilgi Üniversitesi Yayınları.

Hamilton, D. and Watkins, D. (2008). Evidence-based design for multiple building types. (1st edition ed.). John Wiley \& Sons, Inc. USA.

Hartig, T., Mitchell, R., de Vries, S. and Frumkin, H. (2014). Nature and health. Annu Rev Public Health, 35, 207-228. https://doi.org/10.1146/annurev-publhealth032013-182443

Herzog, T. R., Colleen, Maguire, P. and Nebel, M. B. (2003). Assessing the restorative components of environments. Journal of Environmental Psychology, 23(2), 159170. https://doi.org/https://doi.org/10.1016/S0272-4944(02)00113-5

Holt-Lunstad, J., Smith, T. B. and Layton, J. B. (2010). Social relationships and mortality risk: a meta-analytic review. PLoS Med, 7(7), 1-20. e1000316. https://doi.org/10.1371/journal.pmed.1000316

Home, R., Hunziker, M. and Bauer, N. (2012). Psychosocial outcomes as motivations for visiting nearby urban green spaces. Leisure Sciences, 34(4), 350-365. https://doi.org/10.1080/01490400.2012.687644

Honold, J., Lakes, T., Beyer, R. and van der Meer, E. (2016). Restoration in urban spaces:Nature views from home, greenways, and public parks. Environment and Behavior, 48(6), 796-825. https://doi.org/10.1177/0013916514568556

Hunt, C. M. (2020). Biophilic Design: How bringing the outside inside makes you happy. Retrieved 12 May 2021 from https://home.howstuffworks.com/green-living/biophilic-design.htm

Hunter, R. F., Christian, H., Veitch, J., Astell-Burt, T., Hipp, J. A. and Schipperijn, J. (2015). The impact of interventions to promote physical activity in urban green space: a systematic review and recommendations for future research. Social science andamp; medicine, 1982(124), 246-256. https://doi.org/10.1016/j.socscimed.2014.11.051

Jackson, L. E. (2003). The relationship of urban design to human health and condition. Landscape and Urban Planning, 64(4), 191-200. https://doi.org/10.1016/s01692046(02)00230-x 
Jansson, M., Vicenzotti, V. and Diedrich, L. (2019). Landscape design based on research: A methodological guide to design-oriented projects for students and teachers in landscape architecture. Swedish, Swedish University of Agricultural Sciences Faculty of Landscape Architecture, Horticulture and Crop Production Science: 44 .

Kaplan, R., et al. (1998). With people in mind : Design and management of everyday nature. Washington, D.C.: Island Press.

Kaplan, S. (1995). The restorative benefits of nature: Toward an integrative framework. Journal of Environmental Psychology, 15(3), 169-182. https://doi.org/https://doi.org/10.1016/0272-4944(95)90001-2

Karaca, E. (2018). Salutogenic approach for designing restorative environments. the Journal of Academic Social Sciences, 67(67), 116-131. https://doi.org/10.16992/asos.13501

Kellert, S. R. (2016). Biophilic urbanism: The potential to transform. Smart and Sustainable Built Environment, 5(1), 4-8. https://doi.org/10.1108/SASBE-10-2015-0035

Kellert, S. R. and Calabrese, E. (2015). The practice of biophilic design. www.biophilicdesign.com Erişim: 16. 01.2021.

Kellert, S. R., et al. (2011). Biophilic design: The theory, science and practice of bringing buildings to life. New Jersey: Wiley.

Kellert, S. R. and Wilson, E. O. (1993). The biophilia hypothesis. Washington, D.C., Island Press.

Kuo, M. (2015). How might contact with nature promote human health? Promising mechanisms and a possible central pathway. Front Psychol, 6, 1093. https://doi.org/10.3389/fpsyg.2015.01093

Lachowycz, K. and Jones, A. P. (2011). Greenspace and obesity: A systematic review of the evidence. Obes Rev, 12(5), 183-189. https://doi.org/10.1111/j.1467789X.2010.00827.x

Lee, I. M., Shiroma, E. J., Lobelo, F., Puska, P., Blair, S. N. and Katzmarzyk, P. T. (2012). Effect of physical inactivity on major non-communicable diseases worldwide: An analysis of burden of disease and life expectancy. Lancet, 380(9838), 219-229. https://doi.org/10.1016/s0140-6736(12)61031-9

Li, D. and Sullivan, W. C. (2016). Impact of views to school landscapes on recovery from stress and mental fatigue. Landscape and Urban Planning, 148, 149-158. https://doi.org/https://doi.org/10.1016/j.landurbplan.2015.12.015

Li, Q., Kobayashi, M., Inagaki, H., Hirata, Y., Li, Y. J., Hirata, K., Shimizu, T., Suzuki, H., Katsumata, M., Wakayama, Y., Kawada, T., Ohira, T., Matsui, N. and Kagawa, T. (2010). A day trip to a forest park increases human natural killer 
activity and the expression of anti-cancer proteins in male subjects. Journal of biological regulators and homeostatic agents, 24(2), 157-165. http://europepmc.org/abstract/MED/20487629

Li, Q., Kobayashi, M., Wakayama, Y., Inagaki, H., Katsumata, M., Hirata, Y., Hirata, K., Shimizu, T., Kawada, T., Park, B. J., Ohira, T., Kagawa, T. and Miyazaki, Y. (2009). Effect of phytoncide from trees on human natural killer cell function. International Journal of Immunopathology and Pharmacology, 22(4), 951-959. https://doi.org/10.1177/039463200902200410

Maas, J., van Dillen, S. M. E., Verheij, R. A. and Groenewegen, P. P. (2009). Social contacts as a possible mechanism behind the relation between green space and health. Health Place, 15(2), 586-595. https://doi.org/10.1016/j.healthplace.2008.09.006

Maas, J., Verheij, R. A., Spreeuwenberg, P. and Groenewegen, P. P. (2008). Physical activity as a possible mechanism behind the relationship between green space and health: A multilevel analysis. BMC Public Health, 8(1), 206. https://doi.org/10.1186/1471-2458-8-206

MacIntyre, T. E., Beckmann, J., Calogiuri, G., Donnell, A. A., Jones, M. V., Madan, C. R., Rogerson, M., Brick, N. E., Nieuwenhuijsen, M. and Gidlow, C. J. (2020). Editorial: Human-Nature Interactions: Perspectives on Conceptual and Methodological Issues. Front Psychol, 11, 1-4. 607888. https://doi.org/10.3389/fpsyg.2020.607888

Mahdavinejad, M. and Abedi, M. (2011). Community-oriented landscape design for sustainability in architecture and planning. Procedia Engineering, 21, 337-344. https://doi.org/10.1016/j.proeng.2011.11.2024

Mazuch, R. (2017). Salutogenic and biophilic design as therapeutic approaches to sustainable architecture. Architectural Design, 87(2), 42-47. https://doi.org/https://doi.org/10.1002/ad.2151

Middle, I., Dzidic, P., Buckley, A., Bennett, D., Tye, M. and Jones, R. (2014). Integrating community gardens into public parks: An innovative approach for providing ecosystem services in urban areas. Urban Forestry and Urban Greening, 13(4), 638-645. https://doi.org/https://doi.org/10.1016/j.ufug.2014.09.001

Moran, D. (2019). Back to nature? Attention restoration theory and the restorative effects of nature contact in prison. Health and Place, 57, 35-43. https://doi.org/https://doi.org/10.1016/j.healthplace.2019.03.005

Mura, G. (2014). Tasarımda ilham kaynağı olarak kullanıc kaynaklı fotoğraflar. Yedi: Sanat, Tasarm ve Bilim Dergisi, 12, 41-51. 
Nieminen, T., Martelin, T., Koskinen, S., Aro, H., Alanen, E. and Hyyppä, M. T. (2010). Social capital as a determinant of self-rated health and psychological wellbeing. Int J Public Health, 55(6), 531-542. https://doi.org/10.1007/s00038-0100138-3

Othman, N., Mohamed, N., Ariffin, M. H. and Razak, M. A. W. A. (2015). Exploring human oriented design in selected botanical gardens in Malaysia. Procedia Social and Behavioral Sciences, 201, 191-200. https://doi.org/10.1016/j.sbspro.2015.08.168

OttawaUniversity. (2020). Office of campus sustainability. Ottawa University. Retrieved 12 May 2021 from https://sustainable.uottawa.ca/community-gardens

Rasidi, M. H., Jamirsah, N. and Said, I. (2012). Urban green space design affects urban residents' social interaction. Procedia - Social and Behavioral Sciences, 68, 464480. https://doi.org/https://doi.org/10.1016/j.sbspro.2012.12.242

Reeves, J. P., Knight, A. T., Strong, E. A., Heng, V., Neale, C., Cromie, R. and Vercammen, A. (2019). The application of wearable technology to quantify health and wellbeing co-benefits from urban wetlands. Front Psychol, 10, 18-40. https://doi.org/10.3389/fpsyg.2019.01840

Shanahan, D. F., Franco, L., Lin, B. B., Gaston, K. J. and Fuller, R. A. (2016). The benefits of natural environments for physical activity. Sports Med, 46(7), 989-995. https://doi.org/10.1007/s40279-016-0502-4

Shanahan, D. F., Lin, B. B., Bush, R., Gaston, K. J., Dean, J. H., Barber, E. and Fuller, R. A. (2015). Toward improved public health outcomes from urban nature. Am J Public Health, 105(3), 470-477. https://doi.org/10.2105/ajph.2014.302324

Sidenius, U., Karlsson Nyed, P., Linn Lygum, V. and U, K. S. (2017). A diagnostic postoccupancy evaluation of the nacadia(r) therapy garden. Int J Environ Res Public Health, 14(8). https://doi.org/10.3390/ijerph14080882

Steg, L., van den Berg, A. E. and de Groot, J. I. M. (2012). Environmental psychology: An introduction. UK.: Wiley.

Sugiyama, T., Leslie, E., Giles-Corti, B., and Owen, N. (2008). Associations of neighbourhood greenness with physical and mental health: Do walking, social coherence and local social interaction explain the relationships? Journal of Epidemiology and Community Health, 62(5), 1-6. https://doi.org/10.1136/jech.2007.064287

Sullivan, W. C., Kuo, F. E. and Depooter, S. F. (2004). The fruit of urban nature:Vital neighborhood spaces. Environment and Behavior, 36(5), 678-700. https://doi.org/10.1177/0193841x04264945 
Türkoğlu, H. (1993). Istanbul'da konut bölgelerine kullanıcıların konut ve yakın çevresinde memnuniyet derecesinin belirlenmesi. İstanbul Teknik Üniversitesi Araştırma Fonu: İstanbul.

Ulrich, R. S. (1984). View through a window may influence recovery from surgery. Science, 224(4647), 420-421. https://doi.org/10.1126/science.6143402

Ulrich, R. S., Simons, R. F., Losito, B. D., Fiorito, E., Miles, M. A. and Zelson, M. (1991). Stress recovery during exposure to natural and urban environments. Journal of Environmental Psychology, 11(3), 201-230. https://doi.org/10.1016/S02724944(05)80184-7

van den Bosch, M. and Ode Sang, A. (2017). Urban natural environments as naturebased solutions for improved public health - A systematic review of reviews. Environ Res, 158, 373-384. https://doi.org/10.1016/j.envres.2017.05.040

White, H. M. (2013). The New York times building, Lobby Garden. Retrieved 15 May 2021 from https://www.architectmagazine.com/project-gallery/the-new-yorktimes-building-lobby-garden

Wilson, E. O. (1994). Biophilia : the human bond with other species. Harvard University Press.

Xue, F., Gou, Z., Lau, S. S.-Y., Lau, S.-K., Chung, K.-H. and Zhang, J. (2019). From biophilic design to biophilic urbanism: Stakeholders' perspectives. Journal of Cleaner Production, 211, 1444-1452. https://doi.org/10.1016/j.jclepro.2018.11.277

Yang, J., Qu, S., Liu, M., Liu, X., Gao, Q., He, W., Ji, J. S. and Bi, J. (2021). Gray cityscape caused by particulate matter pollution hampers human stress recovery. Journal of Cleaner Production, 279, 1-11. https://doi.org/10.1016/j.jclepro.2020.123215

Ziegler, E. (2014). Application of a salutogenic design model to the architecture of low-income housing. Master. Applied Science, Faculty of Architecture and Landscape Architecture. Canada, University of British Columbia.

\section{Citation Information}

Karaca, E. and Karaca, M. (2021). Environmental psychology approaches within the relationship of nature and health in terms of landscape architecture. OPUS-International Journal of Society Studies, 18(42), 5781-5802. DOI: 10.26466/opus.910271. 